\title{
RATIONALE OF THE METHODOLOGY CLASSIFICATION OF MEDICATION RELATED ERRORS DURING THE RETAIL SALES OF DRUGS IN UKRAINE
}

\author{
A. Kotvitska, I. Surikova
}

\begin{abstract}
Мета. Обтрунтування методології класифікачії ліко-пов'язаних помилок (Л-ПП) під час роздрібної реалізациї лікарських засобів в Україні

Матеріали та методи. За допомогою системно-аналітичного, статистичного, порівняльного методів аналізу, а також описового та абстрактного модулювання й узагальнення нами було досліджено вітчизняні та іноземні наукові публікації та нормативно-правова база.

Результати. Аналіз сучасного стану вітчизняної системи фармаконгляду, показав, щзо нею передбачено повідомлення про випадки появи побічних реакцій ЛЗ, відсутності їх ефективності, однак відсутні категорії, які б характеризували помилки, пов'язані з ЛЗ, зокрема під час роздрібної реалізації в аптечних закладах та самолікуванні. Разом з тим, незважаючи на відсутність єдиної уніфікованої класифікації ЛПП, можна виділити основні категорії Л-ПП та згрупувати їх за етапами виникнення: Л-ПП, щзо трапляються під час призначення ЛЗ, застосування ЛЗ під час стаціонарного лікування, та при відпуску ЛЗ фармачевтичним працівником. За результатами порівняльного аналізу міжнародних систем класифікаціий та моніторингу Л-ПП визначено, щзо більшість з них включають категорії Л-ПП пов'язані з дозою, умовами та тривалістю прийому ЛЗ, відповідності призначень ЛЗ пацієнтові, дотримання пацієнтом призначеної / рекомендованої фармакотерапії та є адаптованими відповідно до умов розвитку галузі охорони здоров'я різних краӥн.

Висновки. Узагальнено підходи до класифікації ліко-пов'язаних помилок та обтрунтовано з урахування загальносвітових та вітчизняних тенденцій розвитку фармацевтичного сектору галузі охорони здоров'я класифікаційну модель Л-ПП, щу може застосовуватися під час роздрібної реалізачії ЛЗ в Україні. Запропонована методологія класифікачї Л-ПП під час роздрібної реалізаџії ЛЗ включає 44 категорії помилок, які в залежності від етапу надання фармацевтичної допомоги розділені на три рівні: помилки під час вибору безрецептурного ЛЗ у ході консультування фармацевтичним працівника, помилки під час відпуску ЛЗ фармацевтичним працівником та помилки на етапі застосування ЛЗ пацієнтом
\end{abstract}

Ключові слова: ліко-пов'язана помилка, фармаконагляд, методологія класифікації, фармацевтична допомога

\section{Introduction}

The current state of development of the pharmaceutical sector of health care, the increase in the number of pharmacies and the nomenclature of drugs, the rapid increase in the pace of life of the population, the current socio-economic conditions and the policy of pharmaceutical manufacturing companies have caused the problem of uncontrolled and irrational use of drugs. According to the World Health Organization (WHO), more than $50 \%$ of all drugs in the world are prescribed, issued or released incorrectly. In this case, $50 \%$ of consumers are mistaken in the method of taking their prescribed medication $[1,2]$.

According to the State Expert Centre of the Ministry of Health of Ukraine (SEC), almost $7.4 \%$ of registered medicines cause adverse reactions recorded in the system of post-registration pharmaceutical surveillance, of which approximately $97 \%$ are related $[1,3]$. At the same time, there are tendencies regarding insufficient information on adverse effects of the use of drugs dur- ing self-medication, uncontrolled use of drugs by patients, uncontrolled dispensing of prescription drugs by pharmacies, inadequate or unqualified pharmaceutical care, etc.

The aim of the research. In view of the aforementioned aim of our study was to substantiate the methodology of classification of drug-related errors (D-RE) during the retail sale of medicines in Ukraine.

\section{Planning (methodology) of research}

In order to substantiate the D-RE classification methodology, we have identified the following stages of the study:

- analysis of the domestic system of pharmaceutical supervision of Ukraine regarding aspects of monitoring of adverse effects of the use of drugs;

- study of international D-RE classification experience;

- comparative analysis of major D-RE classification and monitoring systems in international practice; 
- development and substantiation of D-RE classification methodology during retail sales of drugs in Ukraine.

\section{Materials and methods}

With the help of system-analytical, statistical, comparative methods of analysis, as well as descriptive and abstract modulation and generalization, we investigated domestic and foreign scientific publications on approaches to the D-RE classification, as well as the regulatory framework regulating the functioning of the pharmaceutical surveillance system in Ukraine.

\section{Result of the research}

By WHO definition, pharmaceutical surveillance (pharmacovigilance) is a scientific field and practice related to the detection, evaluation, understanding and prevention of adverse effects or any other problems related to drugs. Supervision of the safety of drugs in their medical application is one of the main directions in the implementation of national policies on drugs in all countries of the world.

Pharmacovigilance in Ukraine is regulated by the order of the Ministry of Health of Ukraine No. 898 of December 27, 2006 "On approval of the Pharmacovigilance Procedure", according to which adverse effects of the use of medicines are also identified, namely a side reaction. It is defined as any unintentional and harmful reaction to drug, and its types as group, predicted, unforeseen, serious, non-serious, as well as the lack of effectiveness of drug - the absence of a favourable diagnostic, therapeutic or prophylactic effect of the drug on establishing the nature of the disease, its course, duration or correction of the condition or physiological functions of the human body according to the indications for use specified in the instructions for medical use [4].

Domestic pharmacovigilance system introduces documented forms of reports on the adverse effects of the use of drugs, namely, Card notifications for providing the patient and / or his representative with information about adverse reactions to drugs, vaccines, tuberculin, and / or lack of effectiveness of drugs, and / or adverse event after immunization / tuberculin diagnostics (Appendix 2 in the version of the Ministry of Health Order \# 996 of 26.09.2016) and Card-report on adverse reaction of drug, vaccine, tuberculin and / or lack of effectiveness of drug, and / for adverse events after immunization / tuberculin (NPPI) (Appendix 6 to the wording of MoH № 996 of 26.09.2016) [5].

In addition to these documented forms, the Automated Pharmacovigilance Information System (AISF) operates in Ukraine, which provides for the filling of card messages on an official website designed to support the process of monitoring adverse reactions or lack of efficacy of drugs in Ukraine [6]. In addition, information on the occurrence of a side effect or lack of effectiveness of drugs can be reported by filling in the appropriate forms on the website of the information-search system "State Register of Medicines", which is the development of the SEC of the Ministry of Health of Ukraine [7].

In the course of studying the domestic system of pharmacovigilance, we found that it provides information on such types of cases as adverse reaction, lack of effica- cy of drugs, adverse event after immunization with a detailed description of the case of their manifestation. However, it is not necessary to indicate the reason that could potentially lead to such cases [5-7].

It should be noted that filling in the Message Cards is intended to provide a message from a health care provider and a patient or his representative. The AISF also includes notifications from the applicant (pharmaceutical manufacturing company), but there is no adaptation regarding errors that occur during the retail sale of drugs or during the self-medication phase [6].

At the same time, as international experience shows, adverse effects of the use of drugs on the patient are not always manifested as a side effect or lack of efficacy of drugs, and are not necessarily the result of therapeutic action of drugs in humans. In recent years, the term "medication error", which is defined as "medication" or "drug-related error", "drug related problem", "drug therapy problem", etc., has been increasingly used in the world to describe the adverse effects of the treatment of patients with pharmaceutical drugs.

In the course of the study, we found that today there is no single system in the world for identifying and classifying related errors. The most common and implemented by various countries at the national level is the definition proposed by the US National Coordinating Council for Reporting and Prevention (NCC MERP), in particular, a drug-related error - any phenomenon (avoidable occurrence) that occurred while using a medication under the control of a healthcare professional, patient, or consumer, and which could lead to the inappropriate use of the medication or cause harm to health patient [8].

International experience shows that different approaches to the classification and monitoring of healthrelated errors are used in the healthcare industry. Comparative analysis of common systems such as Cipolle / Morley / Strand classification, Granada Consensus DRP Classification, NCC MERP, Pharmaceutical Care Network Europe (PCNE) Classification V 8.03, Problemintervention documentation (PI-Doc), SHB-SEP classification and Westerlund system presented in the Table 1.

According to the research of different monitoring systems for drug-related errors, it is determined that the error message can be made by different healthcare professionals, namely, doctors, nurses, clinical pharmacists, pharmaceutical workers of pharmacy establishments, as well as patients who use the drug, or its representative.

Most classification systems include categories related to dose, conditions and duration of medication administration, appropriateness of medication prescribing to the patient, compliance with prescribed / recommended pharmacotherapy by the patient. In addition, systems such as the Granada Consensus DRP Classification, Problem-Intervention Documentation (PI-Doc), the SHBSEP classification, and the Westerlund system have been developed by governmental authorities in the field of pharmacy or professional associations and include elements specific to their health care systems. In general, the study of different types and approaches to the classification of D-RE provides an opportunity to generalize the tendencies for their classification and define criteria (Fig. 1) [9]. 
Comparative analysis of major classification systems and monitoring of drug-related errors

\begin{tabular}{|c|c|c|c|c|c|}
\hline \multirow{2}{*}{ The name of the system } & \multirow{2}{*}{$\begin{array}{l}\text { Country, year of } \\
\text { introduction }\end{array}$} & \multirow{2}{*}{$\begin{array}{l}\text { Characteristics of the monitoring } \\
\text { system }\end{array}$} & \multicolumn{3}{|c|}{$\begin{array}{l}\text { Ability to report different sub- } \\
\text { jects on D-RE }\end{array}$} \\
\hline & & & $\begin{array}{l}\text { Hospital } \\
\text { level }\end{array}$ & $\begin{array}{c}\text { Pharmacy } \\
\text { level }\end{array}$ & $\begin{array}{c}\text { Patient } \\
\text { level }\end{array}$ \\
\hline $\begin{array}{l}\text { Cipolle/Morley/Strand } \\
\text { classification }\end{array}$ & USA; 1999 & $\begin{array}{l}\text { The system is being implemented } \\
\text { by US retail pharmacies to eval- } \\
\text { uate the work of pharmacies in } \\
\text { providing pharmaceutical care. }\end{array}$ & + & & \\
\hline $\begin{array}{l}\text { Granada Consensus DRP } \\
\text { Classification }\end{array}$ & $\begin{array}{l}\text { Spain, Portugal; } \\
1998\end{array}$ & $\begin{array}{l}\text { The classification is based on } \\
\text { negative clinical results by cate- } \\
\text { gory of indication, efficacy, } \\
\text { drug, safety }\end{array}$ & + & + & + \\
\hline NCC MERP & USA; 1996 & $\begin{array}{l}\text { The D-RE classification is con- } \\
\text { ducted in } 9 \text { categories (A-I) ac- } \\
\text { cording to the severity of the } \\
\text { effects of the use of drugs }\end{array}$ & + & & + \\
\hline $\begin{array}{l}\text { Pharmaceutical Care Net- } \\
\text { work Europe (PCNE) Clas- } \\
\text { sification V } 8.03\end{array}$ & $\begin{array}{l}\text { Finland, Swit- } \\
\text { zerland, Nether- } \\
\text { lands, Sweden, } \\
\text { Great Britain, } \\
\text { Belgium, Aus- } \\
\text { tria; } \\
1999\end{array}$ & $\begin{array}{l}\text { PCNE Classification constantly } \\
\text { reviewed in line with changes in } \\
\text { the health care system. The fol- } \\
\text { lowing components are included } \\
\text { in the system: } \\
\text { problems ( } 3 \text { categories, which } \\
\text { include } 7 \text { D-RE); } \\
\text { - causes ( } 8 \text { categories } 37 \text { causes of } \\
\text { D-RE); } \\
\text { - interventions ( } 4 \text { categories and } 16 \\
\text { possible interventions that may stop } \\
\text { D-RE); } \\
\text { - deciding on intervention ( } 3 \text { cate- } \\
\text { gories and } 10 \text { D-RE intervention } \\
\text { results); } \\
\text { - D-RE status ( } 7 \text { categories of } \\
\text { current D-RE status) }\end{array}$ & + & + & + \\
\hline $\begin{array}{l}\text { Problem-intervention doc- } \\
\text { umentation (PI-Doc) }\end{array}$ & $\begin{array}{l}\text { Germany, } \\
\text { Denmark; } 1995\end{array}$ & $\begin{array}{l}\text { The hierarchical system for PI- } \\
\text { Doc is designed with ease of use } \\
\text { in a pharmacy facility and im- } \\
\text { plemented in most German } \\
\text { pharmacy pharmaceutical infor- } \\
\text { mation systems. }\end{array}$ & & + & + \\
\hline SHB-SEP classification & $\begin{array}{l}\text { Netherlands; } \\
2003\end{array}$ & $\begin{array}{l}\text { The system, which includes the } \\
\text { D-RE categories both in terms of } \\
\text { the patient and the level of phar- } \\
\text { macies, is implemented in phar- } \\
\text { macies and is regularly reviewed. }\end{array}$ & & + & + \\
\hline Westerlund system & Sweden, 2001 & $\begin{array}{l}\text { The classification is based on } \\
\text { circumstances related to the use } \\
\text { of drugs that actually or poten- } \\
\text { tially prevent the patient from } \\
\text { obtaining the desired benefit of } \\
\text { the drugs. }\end{array}$ & & + & + \\
\hline
\end{tabular}

Taking into account the results of the review of the different D-RE classification systems and the tendencies characteristic of the domestic healthcare sector, in particu- lar, the uncontrolled dispensing of prescription drugs, we have developed a classification model that can be applied during the retail sale of drugs in Ukraine (Table 2). 


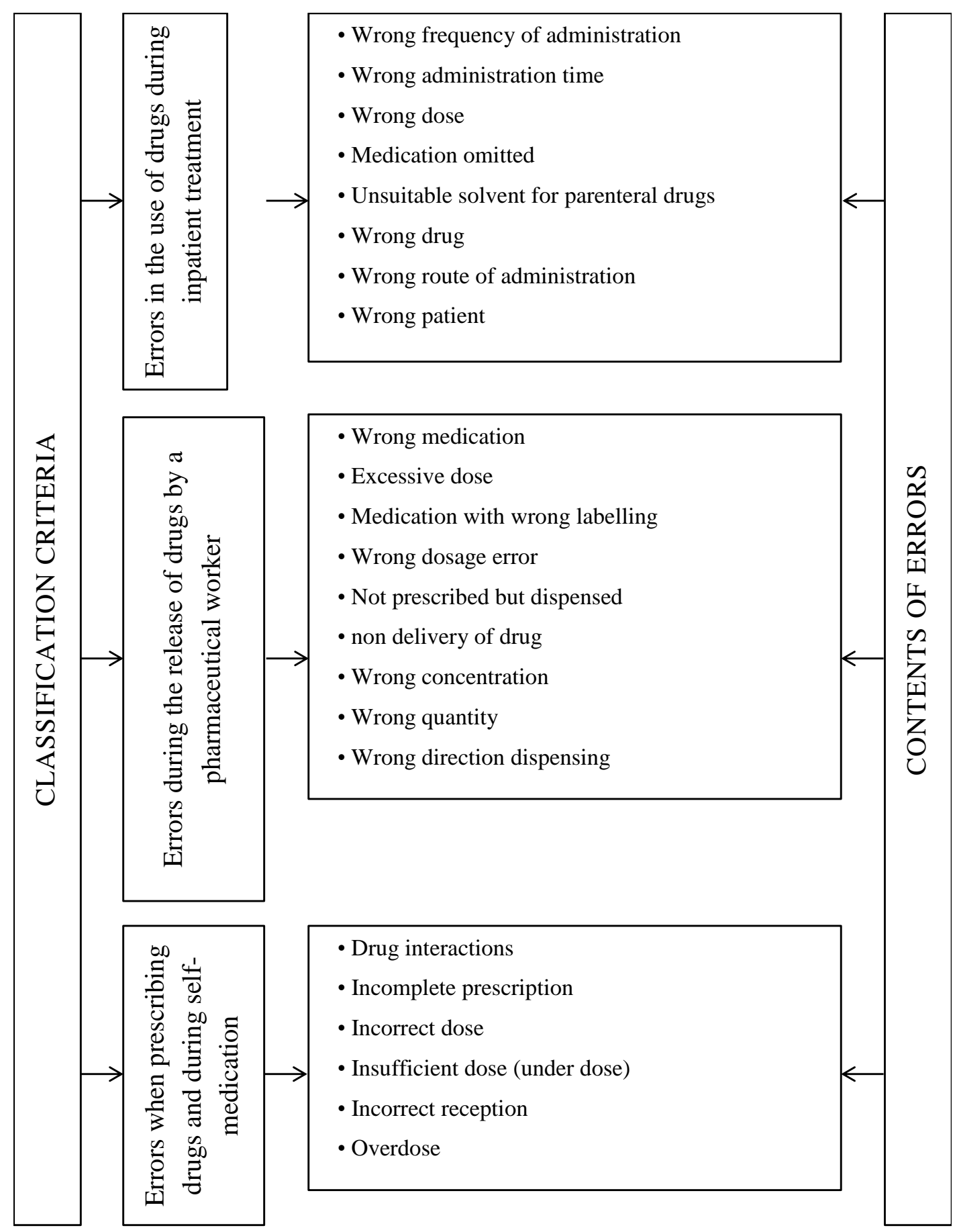

Fig. 1. Generalization of global trends for classification of drug-related errors by criteria

Our methodology for classifying slightly drugrelated errors during the retail sale of drugs consists of 29 categories of errors, which are divided into two levels depending on the stage of providing pharmaceutical assistance: errors in the choice of OTC drugs in the process of pharmaceutical counselling and errors during the release of drugs by a pharmaceutical worker.

It should also be noted that the error categories B 6.1 - B 6.5 and B 9 provide administrative liability under the Code of Administrative Offenses (Articles 42-
4, 167, 168-1, 170) [10]. However, in our opinion, given the current trends in the state and development of the pharmaceutical sector in the healthcare sector, it is important to include these categories in the classification model at the initial stage of implementation of the monitoring system for drug-related errors. In the future, the D-RE classification system may be revised in connection with the reform of the health care system and the new challenges facing pharmaceutical workers. 
Methodology for classifying drug-related errors during the retail sale of medicines

\begin{tabular}{|c|c|c|c|c|c|}
\hline Error code & Error stage & \multicolumn{4}{|c|}{ The contents of the error } \\
\hline A 1 & \multirow{14}{*}{$\begin{array}{l}\text { The choice of } \\
\text { OTC drugs in } \\
\text { the process of } \\
\text { consulting by } \\
\text { pharmaceutical } \\
\text { worker }\end{array}$} & \multicolumn{4}{|c|}{ Non-compliant drug as recommended by the prescriber / form / protocol } \\
\hline A 2 & & \multicolumn{4}{|c|}{ Absence of indications in the patient for use of drugs } \\
\hline A 3 & & \multicolumn{4}{|c|}{ Incorrect combination of drugs } \\
\hline A 4 & & \multicolumn{4}{|c|}{ Inappropriate drug dosage form (for a specific patient) } \\
\hline A 5 & & \multicolumn{4}{|c|}{ Improper duplication of therapeutic group or active ingredient } \\
\hline A 6 & & \multicolumn{4}{|c|}{$\begin{array}{l}\text { Improper replacement of a drug appointed by a physician within one treatment } \\
\text { group }\end{array}$} \\
\hline A 7.1 & & \multirow{5}{*}{$\begin{array}{l}\text { Inappropriate } \\
\text { dose }\end{array}$} & \multicolumn{3}{|c|}{ Drug dose is overstated } \\
\hline A 7.2 & & & \multicolumn{3}{|c|}{ Drug dose is lowered } \\
\hline A 7.3 & & & \multicolumn{3}{|c|}{ The dosage regimen is overstated } \\
\hline A 7.4 & & & \multicolumn{3}{|c|}{ The dosage regimen is lowered } \\
\hline A 7.5 & & & \multicolumn{3}{|c|}{ Dosing instructions are incorrect, unclear or missing } \\
\hline A 8 & & \multicolumn{4}{|c|}{ Inappropriate duration of use of drugs } \\
\hline A 9 & & \multicolumn{4}{|c|}{$\begin{array}{l}\text { Lack of control of individual characteristics of the patient (pregnant women, chil- } \\
\text { dren, chronic patients, etc.) }\end{array}$} \\
\hline A 10 & & \multicolumn{4}{|c|}{ Recommendation of a prescription drug } \\
\hline B 1 & \multirow{15}{*}{$\begin{array}{l}\text { Dispensing of a } \\
\text { medication by a } \\
\text { pharmaceutical } \\
\text { worker }\end{array}$} & \multicolumn{4}{|c|}{ Wrong release of drugs with inappropriate pharmacological action } \\
\hline B 2 & & \multicolumn{4}{|c|}{ Release of inappropriate drugs within one pharmacotherapeutic group } \\
\hline B 3 & & \multicolumn{4}{|c|}{ Release of incorrect dose of drugs } \\
\hline B 4 & & \multicolumn{4}{|c|}{ Release of incorrect dosage form of drugs } \\
\hline B 5 & & \multicolumn{4}{|c|}{ Release of medicines in the wrong amount } \\
\hline B 6.1 & & \multirow{5}{*}{$\begin{array}{l}\text { Release of poor } \\
\text { quality drugs }\end{array}$} & \multicolumn{2}{|c|}{ Drugs with expired shelf life } & $\mathrm{AO}$ \\
\hline B 6.2 & & & \multicolumn{2}{|r|}{ Absence of necessary marking of packaging of drugs } & $\mathrm{AO}$ \\
\hline B 6.3 & & & \multicolumn{2}{|r|}{ Loss of marketable appearance of packaging } & $\mathrm{AO}$ \\
\hline B 6.4 & & & \multicolumn{2}{|r|}{ A drug that has not been properly stored at the pharmacy } & $\mathrm{AO}$ \\
\hline B 6.5 & & & & ged drugs & $\mathrm{AO}$ \\
\hline B 7 & & \multicolumn{4}{|c|}{ The release of drug, which is in "quarantine" } \\
\hline B 8.1 & & \multirow{3}{*}{\multicolumn{2}{|c|}{$\begin{array}{l}\text { The absence of } \\
\text { reservations on the } \\
\text { use of drugs when } \\
\text { they need }\end{array}$}} & \multicolumn{2}{|l|}{ No warning about interaction with other drugs } \\
\hline B 8.2 & & & & $\begin{array}{l}\text { No warning about the interaction of drugs with } \\
\text { alcohol }\end{array}$ & d and \\
\hline B 8.3 & & & & No warning regarding specific storage conditions & drugs \\
\hline B9 & & Release of presc & iptic & drugs without prior prescribing by a doctor & $\mathrm{AO}$ \\
\hline
\end{tabular}

\section{Discussion of the results}

Considering the concept of responsible self-care [11], it is important to involve patients in the monitoring and prevention of drug-related errors.
Therefore, we have also substantiated the classification system of minor errors during the use of drugs by the patient, which includes 15 categories of errors (Table 3).

Table 3

A methodology for classifying drug-related errors in the concept of responsible self-care

\begin{tabular}{|c|c|c|c|}
\hline Error code & Error stage & & The contents of the error \\
\hline $\mathrm{C} 1$ & \multirow{15}{*}{$\begin{array}{c}\text { The use of } \\
\text { drugs by the } \\
\text { patient }\end{array}$} & \multicolumn{2}{|c|}{ Do not use the patient's prescribed / recommended drugs } \\
\hline $\mathrm{C} 2$ & & \multicolumn{2}{|c|}{ Use of unnecessary drugs by the patient } \\
\hline C 3.1 & & \multirow{2}{*}{$\begin{array}{l}\text { Incorrect dosage of } \\
\text { drugs by the patient }\end{array}$} & Administration of smaller dose of drugs \\
\hline C 3.2 & & & Administration of larger dose of drugs \\
\hline $\mathrm{C} 4$ & & \multicolumn{2}{|l|}{ Drug abuse (addictive) } \\
\hline C 5 & & \multicolumn{2}{|c|}{$\begin{array}{l}\text { Inadequate duration of use of drugs (prescribed / recommended drug course not fully } \\
\text { completed) }\end{array}$} \\
\hline $\mathrm{C} 6$ & & \multicolumn{2}{|c|}{ Reception of concomitant drugs that affect the prescribed / recommended drugs } \\
\hline C 7.1 & & \multirow{5}{*}{$\begin{array}{l}\text { Incorrect mode of drug } \\
\text { administration }\end{array}$} & The dosage regimen is overstated \\
\hline C 7.2 & & & The dosage regimen is lowered \\
\hline C 7.3 & & & Inappropriate time of day \\
\hline C 7.4 & & & Improper use before meals \\
\hline C 7.5 & & & Other \\
\hline C 8 & & \multicolumn{2}{|c|}{ The use of drugs the wrong route of administration } \\
\hline C 9 & & \multicolumn{2}{|c|}{ Inability to take the prescribed / recommended dosage form for a particular patient } \\
\hline C 10 & & \multicolumn{2}{|l|}{ Other } \\
\hline
\end{tabular}


Thus, it can be argued that the presented classification model will promote the rational, safe and effective use of drugs, both prescription and over-the-counter, in particular, reduce the number of cases of errors associated with the use of drugs by the patient, as well as identify a new role for the pharmaceutical worker in modern conditions providing pharmaceutical assistance in Ukraine.

\section{Conclusions}

We generalized approaches to classification of drug-related errors (D-RE) and substantiate of the classification model that can be applied during retail sales of drugs in Ukraine.

The analysis of the functioning of the domestic pharmacovigilance system, which provides reports of occurrences of adverse drug reactions, lack of their effectiveness, but no categories characterizing errors related to drugs, in particular during retail sales in pharmacies.

Based on the comparative analysis of 7 major international D-RE classification and monitoring systems, most of them include D-RE categories related to dose, conditions and duration of medication administration, compliance with the patient's prescribing, compliance with prescribed / recommended pharmacotherapy, and adapted to the conditions of development of the healthcare sector of different countries.

It is established that today there is no single unified D-RE classification in the world. Taking into account the general trends, it is possible to distinguish errors that occur during the prescribing of drugs, the use of drugs during inpatient treatment, and when pharmaceutical worker dispense drugs.

Based on the international experience and current state of the national healthcare sector, and taking into account the concept of responsible self-medication, we have proposed a D-RE classification methodology for the retail sale of drugs, consisting of 44 error categories, which, depending on the stage of providing pharmaceutical assistance divided into three levels: errors in the selection of OTC drugs in the course of consulting by pharmacist, errors in the release of drugs by a pharmacist and errors at the stage of medication use by the patient.

\section{References}

1. Lebega O., Nwokike J., Walkowiak H. (2012) Safety of Medicinal Products in Ukraine: Assessment of the Pharmacovigilance System and its Performance. Submitted to the U.S. Agency for International Development by the Strengthening Pharmaceutical Systems (SPS) Program. Arlington, 123

2. Masheiko, A. M., Podpletnia, O. A., Zaiarskyi, M. I., Zalyhina, Ye. V., Kukhar, O. P. (2011). Role of the pharmacist in the successful implementation of conception of responsible self-medication. Farmatsevtychnyi zhurnal, 3 (7), 27-33.

3. Derzhavnyi ekspertnyi tsentr Ministerstva okhorony zdorovia Ukrainy. Available at: http://www.dec.gov.ua/

4. Pro zatverdzhennia Poriadku zdiisnennia nahliadu za pobichnymy reaktsiiamy likarskykh zasobiv, dozvolenykh do medychnoho zastosuvannia (2006). Zakon Ukrainy No. 898. 27.12.2006. Available at: https://zakon.rada.gov.ua/laws/show/z0073-07

5. Pro vnesennia zmin do deiakykh nakaziv Ministerstva okhorony zdorovia Ukrainy (2016). Nakaz MOZ Ukrainy No. 996. 29.09.2016. Available at: https://zakon.rada.gov.ua/laws/show/z1649-16

6. Avtomatyzovana informatsiina systema z farmakonahliadu. Available at: https://aisf.dec.gov.ua

7. Derzhavnyi reiestr likarskykh zasobiv. Available at: http://www.drlz.com.ua/

8. The National Coordinating Council for Medication Error Reporting and Prevention. Available at: http://www.nccmerp.org/

9. Kotvitska, A. A., Surikova, I. O. (2019). Study of negative outcomes in the results of using medicines by patients in Ukraine and abroad. Management, Economics and Quality Assurance in Pharmacy, 2 (58), 46-52. doi: http://doi.org/10.24959/uekj.19.14

10. Kodeks Ukrainy pro administratyvni pravoporushennia: za stanom na 29 zhovtnia 2019 r. Vidomosti Verkhovnoi Rady Ukrainskoi RSR. Available at: http://zakon3.rada.gov.ua/laws/show/80731-10

11. Joint Statement by The International Pharmaceutical Federation and The World Self-Medication Industry. Responsible Self-Medication. Available at: https://www.fip.org/file/1484

Received date 09.01.2020

Accepted date 28.01.2020

Published date 29.02.2020

Alla Kotvitska, Doctor of Pharmaceutical Sciences, Professor, Department of Social Pharmacy, National University of Pharmacy, Pushkinska str., 53, Kharkiv, Ukraine, 61002

E-mail: socpharm@nuph.edu.ua

Iryna Surikova, Department of Social Pharmacy, National University of Pharmacy, Pushkinska str., 53, Kharkiv, Ukraine, 61002

E-mail: socpharm@nuph.edu.ua 